$\angle$ Research Square

\title{
Gadolinium oxide nanoparticles enhance the cytotoxicity of chemotherapeutic drugs by blocking autophagic flux in cancer cells
}

\section{Tianyu Zhang}

Wuhan University https://orcid.org/0000-0001-5188-2662

Cheng Zhong

Wuhan University

Zhixiong Xie ( $\nabla$ zxie@whu.edu.cn )

Research article

Keywords: Gd203 NPs, chemotherapy, chemosensitizer, autophagy

Posted Date: July 17th, 2019

DOI: https://doi.org/10.21203/rs.2.11478/v1

License: (a) (i) This work is licensed under a Creative Commons Attribution 4.0 International License. Read Full License 


\section{Abstract}

During chemotherapy, drugs can damage cancer cells' DNA and cytomembrane structure, and then induce cell death. However, autophagy can increase the chemotherapy resistance of cancer cells, reducing the effect of chemotherapy. We found that gadolinium oxide nanoparticles (Gd2O3 NPs), which have great potential for use as a contrast agent in magnetic resonance imaging, could block the late stage of autophagic flux in a dose-dependent manner and then cause autophagosome accumulation in HeLa cells. When co-treated with $8 \mu \mathrm{g} / \mathrm{mL}$ Gd2O3 NPs and $5 \mu \mathrm{g} / \mathrm{mL}$ cisplatin, the number of dead cancer cells increased by about $20 \%$ compared with cisplatin alone. We observed the same phenomenon in cisplatin-resistant COC1/DDP cells. Thus, Gd203 NPs have significant potential for use in both cancer diagnosis and therapy.

\section{Background}

Cancer is a malignant invasion and uncontrolled growth of cells [1] and much energy and other resources are wasted at tumor sites. Chemotherapy is a common treatment for cancer; during chemotherapy, the chemical drugs can cause DNA damage and cell function failure [2], which can induce cell death [3].

In oncology, drug resistance is the dominant obstacle for therapy efficacy, and autophagy may help cancer cells to survive chemotherapy, to some extent, thereby leading to drug resistance [4]. In cells, material such as disabled organelles and proteins become coated by double-membranes in structures named autophagosomes [5]. Subsequently, the autophagosomes fuse with lysosomes, forming autolysosomes, in which the encapsulated contents are degraded into components for use in repair or cell structure formation. Cells perceive nanoscale materials to be foreign or aberrant, and these nanoscale materials can disturb the process of macroautophagy (defined in this article as autophagy) and cause lysosomal dysfunction [6]. Recently, our group reported that cadmium telluride quantum dots can block the late stage of autophagic flux in Saccharomyces cerevisiae and were toxic to the cells [7]. In addition, several other nanomaterials (such as fullerene $\mathrm{C} 60$ nanocrystals and $\mathrm{MnO}$ nanocrystals) have been reported to have potential to treat cancer by disturbing the autophagy process [8,9]. Thus, using nanoparticles (NPs) as chemosensitizers to induce disruptions to the autophagic flux is a new method to treat cancer. The use of an autophagic inhibitor in combination with chemotherapeutic agents has already shown significant potential in cancer therapy $[10,11]$.

Gadolinium oxide $\left(\mathrm{Gd}_{2} \mathrm{O}_{3}\right)$ nanoscale materials were developed to be used as contrast agents for magnetic resonance imaging (MRI) due to their longitudinal relaxivity characteristics [12]. They have significant potential for improving image quality. For example, terbium-doped $\mathrm{Gd}_{2} \mathrm{O}_{3} \mathrm{NPs}$ can be used as a fluorescence and MRI dual-modal contrast agent [13]. Due to the better T1 contrast enhancement compared to $\mathrm{Gd} 3$ + chelates, $\mathrm{Gd}_{2} \mathrm{O}_{3} \mathrm{NPs}$ are recognized as promising potential MRI T1 contrast agents $[14,15]$. The ability of $\mathrm{Gd}_{2} \mathrm{O}_{3} \mathrm{NPs}$ (which were used in this study) to enhance $\mathrm{T} 1$ contrast was previously reported [16]. 
Faucher et al reported that $\mathrm{Gd}_{2} \mathrm{O}_{3} \mathrm{NPs}$ could agglomerate in vesicles and be retained in glioblastoma multiforme cells [17]. Thus, the persistence of $\mathrm{Gd}_{2} \mathrm{O}_{3} \mathrm{NPs}$ may influence the cellular degradation system. Autophagy is a major intracellular degradation process that involves delivering cytoplasmic constituents sequestered in double-membrane vesicles to lysosomes [18], and it is particularly important for cells under certain environmental stress conditions [19]. Li et al reported that $\mathrm{Gd}_{2} \mathrm{O}_{3} \mathrm{NPs}(47 \mathrm{~nm})$ induced autophagosome accumulation in THP-1 cells [20], but full details of the autophagic response to $\mathrm{Gd}_{2} \mathrm{O}_{3}$ NPs remain unknown.

We aimed to explore autophagic changes after cell expose to $\mathrm{Gd}_{2} \mathrm{O}_{3} \mathrm{NPs}$ by monitoring autophagic markers. In addition, to explore whether $\mathrm{Gd}_{2} \mathrm{O}_{3}$ NPs can treat cancer by disrupting cancer cells' autophagic function, we co-treated HeLa cells and cisplatin-resistant COC1/DDP cells with $\mathrm{Gd}_{2} \mathrm{O}_{3} \mathrm{NPs}$ and cisplatin. If the $\mathrm{Gd}_{2} \mathrm{O}_{3}$ NPs used in our work can enhance the ability of chemical drugs to kill cancer cells by modulating autophagy, the $\mathrm{Gd}_{2} \mathrm{O}_{3}$ NPs would offer a new avenue for both cancer diagnosis and therapy.

\section{Methods}

Preparation of $\mathrm{Gd}_{2} \mathrm{O}_{3} \mathrm{NPs}$

The $\mathrm{Gd}_{2} \mathrm{O}_{3}$ NPs were provided by Prof. Jinhao Gao [16]. The collected product was purified by dialysis. The concentrations of gadolinium ions in the NPs were measured by inductively coupled plasma atomic emission spectroscopy (ICP-AES).

Cell culture and treatment

HeLa and COC1/DDP cells were purchased from China Center for Type Culture Collection (Wuhan, China). Fetal bovine serum (FBS) was purchased from Biological Industries (Kibbutz Beit Haemek, Israel). Antibiotics were purchased from Gibco (Grand Island, NY, USA). The cells were cultured in Dulbecco's Modified Eagle Medium (DMEM; HeLa) or Roswell Park Memorial Institute (RPMI) 1640 medium (COC1/DDP) supplemented with $10 \%$ FBS and antibiotics $(100 \mu \mathrm{g} / \mathrm{mL}$ streptomycin and $100 \mathrm{U} / \mathrm{mL}$ penicillin) at $37^{\circ} \mathrm{C}$ and $5 \% \mathrm{CO}_{2}$.

For the treatment experiments, cells were grown at an appropriate density in 96- or 6-well plates for $24 \mathrm{~h}$ to reach $80 \%$ population. Thereafter, the cells were cultured in fresh medium supplemented with the treatments (add rapamycin (Rapa, $20 \mu \mathrm{M}$ ), chloroquine (CQ, $100 \mathrm{nM}), \mathrm{Gd}_{2} \mathrm{O}_{3} \mathrm{NPs}(2,4$ or $8 \mu \mathrm{g} / \mathrm{mL}$ ), cisplatin (5 or $10 \mu \mathrm{g} / \mathrm{mL}$ ) alone or several of them together into the fresh medium).

Autophagy assay

Autophagosomes number changes were measured by monodasylcadaverine (MDC) staining, MDC is a selective fluorescent marker for autophagic vacuoles [21], to observe the autophagic process using 
fluorescence microscopy, Rapa (an agent that can induce autophagy) and CQ (a lysosomal inhibitor) were used as positive controls. And also measured by analysis of microtubule-associated protein light chain 3 (LC3) immunoblot, ratio of LC3-II/GADPH was used to quantification of LC3-II. Autophagic flux status was measured by analysis of p62 immunoblot.

Immunofluorescence

After treatment of the cells in 6-well plates for $24 \mathrm{~h}$, the supernatants were removed. The cells were then fixed with $4 \%$ paraformaldehyde at room temperature for $20 \mathrm{~min}$. Subsequently, $1 \mathrm{~mL} 0.5 \%$ Triton X-100 was added to each well, and the cells were left for $20 \mathrm{~min}$. Thereafter, the cells were probed with primary rabbit polyclonal anti-LC3 antibody (Danvers, MA, USA, Cell Signaling Technology) overnight at $4{ }^{\circ} \mathrm{C}$, and the secondary antibody, horseradish peroxidase-conjugated goat anti-rabbit lgG (Proteintech, Wuhan, China), was then added and the cells were incubated for $2 \mathrm{~h}$ at room temperature. Finally, after adding 1 $\mathrm{mL}$ 4',6-diamidino-2-phenylindole (DAPI, final concentration $0.1 \mu \mathrm{g} / \mathrm{mL}$ ) to each well and leaving the cells for 6 min at $37^{\circ} \mathrm{C}$, the cells were observed by confocal microscopy (Olympus, Tokyo, Japan).

Protein extraction and immunoblot analysis

Cells were lysed in sodium dodecyl sulfate (SDS) lysis buffer (P0013B; Beyotime, Shanghai, China) with 1 $\mathrm{mM}$ phenylmethylsulfonyl fluoride (PMSF) on ice. Thereafter, the cell lysates were heated at $95^{\circ} \mathrm{C}$ for 20 min and centrifuged at $13,500 \times \mathrm{g}$ for $10 \mathrm{~min}$ at $4{ }^{\circ} \mathrm{C}$. The supernatant was collected and the protein concentration was determined with a Bicinchoninic Acid (BCA) Kit (P0012 BCA; Beyotime, Shanghai, China).

Samples were run on 15\% SDS-polyacrylamide gel electrophoresis (PAGE) gels and transferred onto polyvinylidene fluoride (PVDF) membranes. Each membrane was blocked with $5 \%$ skimmed milk and $0.1 \%$ Tween-20 overnight at $4^{\circ} \mathrm{C}$ and probed with LC3 or p62 or GAPDH primary antibody for $2 \mathrm{~h}$. Regarding the secondary antibody, the incubation was performed with horseradish peroxidaseconjugated IgG for $2 \mathrm{~h}$. Blots were developed using a chemiluminescent horseradish peroxidase substrate (Merck Millipore, Billerica, MA, USA). Each Western blot was analyzed using Image J software (National Institutes of Health, Bethesda, MD, USA).

Cell viability assay

Cell viability was measured using a (4,5-dimethylthiazol-2-yl)-2,5-diphenyltetrazolium bromide (MTT) assay. After treatment, medium supplemented with MTT solution was added to each well and the cultures were incubated for $4 \mathrm{~h}$ at $37^{\circ} \mathrm{C}$. Thereafter, the supernatants were removed and $100 \mu \mathrm{L}$ dimethyl sulfoxide (DMSO) was added to the plates, which were then incubated for $10 \mathrm{~min}$ at $37^{\circ} \mathrm{C}$. The absorbance at $595 \mathrm{~nm}$ was detected using a microplate reader (Thermo, Grand Island, NY, USA).

Apoptosis assay 
Apoptosis detection was performed with an Annexin V-Fluorescein Isothiocyanate (FITC) Apoptosis Detection Kit (C1062; Beyotime, Shanghai, China). Briefly, after $24 \mathrm{~h}$ treatment cells were stained by Annexin V-FITC and propidium iodide (PI) for $15 \mathrm{~min}$ at room temperature, avoiding light, and analyzed using a BD FACSAria flow cytometer (BD Biosciences, San Jose, CA, USA).

Statistical analysis

Each experiment was performed in three replicates, and the values shown represent the means \pm standard deviation. Significant differences between the treatments were determined by Student's $t$-test using SigmaPlot Version 12.5 (Systat Software, San Jose, CA, USA).

\section{Results}

$\mathrm{Gd}_{2} \mathrm{O}_{3}$ NPs cause autophagosome accumulation in HeLa cells

To investigate the effect of $\mathrm{Gd}_{2} \mathrm{O}_{3} \mathrm{NPs}$ on autophagy, firstly, we used MDC staining, after treatment of HeLa cells with 4 and $8 \mu \mathrm{g} / \mathrm{mL} \mathrm{Gd}_{2} \mathrm{O}_{3} \mathrm{NPs}$, we observed increased numbers of MDC-labeled vesicles compared to in the control cells, and this effect was dose-dependent (Fig. 1A). This indicated that $\mathrm{Gd}_{2} \mathrm{O}_{3}$ NPs could induce the accumulation of autophagic vacuoles in HeLa cells.

In detail, immunofluorescence and immunoblotting analysis of LC3 were conducted. LC3 is the most widely used biomarker for autophagosomes [22], and the amount of LC3-II has a positive correlation with the autophagy level [23]. As shown in Fig. 1B, 4 and $8 \mu \mathrm{g} / \mathrm{mL} \mathrm{Gd}_{2} \mathrm{O}_{3} \mathrm{NPs}$ induced significant accumulation of autophagosomes stained with LC3 antibody. In addition, $\mathrm{Gd}_{2} \mathrm{O}_{3} \mathrm{NP}$ treatment resulted in an increase of LC3-II, and the amount of LC3-II increased in a dose-dependent manner (Fig. 1C and D). Taken together, these results indicate that $\mathrm{Gd}_{2} \mathrm{O}_{3} \mathrm{NPs}$ induced accumulation of autophagosomes in a dose-dependent manner.

Autophagosome accumulation is caused by inhibition of late-stage autophagic flux rather than induction of autophagy

Accumulation of autophagosomes could be the result of induction of autophagy or inhibition of autophagosome clearance [24]. To determine what the case for $\mathrm{Gd}_{2} \mathrm{O}_{3}$ NPs was, we measured the turnover of LC3 in the presence or absence of $100 \mathrm{nM}$ CQ and $20 \mu \mathrm{M}$ Rapa, respectively. Rapa caused LC3-II accumulation as expected and adding CQ further increased the Rapa-induced LC3-II accumulation. No increase in LC3-II accumulation was found in cells co-treated with $8 \mu \mathrm{g} / \mathrm{mL} \mathrm{Gd}_{2} \mathrm{O}_{3} \mathrm{NPs}$ and CQ compared to cells treated with $\mathrm{Gd}_{2} \mathrm{O}_{3} \mathrm{NPs}$ alone (Fig. $2 \mathrm{~A}$ and B). This indicated that $\mathrm{Gd}_{2} \mathrm{O}_{3} \mathrm{NPs}$ caused 
autophagosome accumulation by inhibiting autophagosome clearance rather than by inducing autophagy.

To further confirm this conclusion, autophagic flux was monitored by measuring p62, a specific substrate that is preferentially degraded by autophagy [25]. As expected, as shown in Fig. 2C and D, $20 \mu \mathrm{M}$ Rapa caused p62 degradation while $100 \mathrm{nM}$ CQ led to p62 accumulation. 4 and $8 \mu \mathrm{g} / \mathrm{mL} \mathrm{Gd}_{2} \mathrm{O}_{3}$ NPs treatment caused accumulation of p62, indicating possible impairment of autophagic degradation capacity. Taken together, these results indicate that $\mathrm{Gd}_{2} \mathrm{O}_{3} \mathrm{NPs}$ induced autophagosome accumulation by inhibition of autophagosome clearance.

$\mathrm{Gd}_{2} \mathrm{O}_{3}$ NPs enhance cytotoxicity of cisplatin in HeLa cells

To find out whether $\mathrm{Gd}_{2} \mathrm{O}_{3}$ NPs can enhance the cytotoxicity of drugs, we firstly investigated the cytocompatibility of $\mathrm{Gd}_{2} \mathrm{O}_{3} \mathrm{NPs}$ in HeLa cells using the MTT procedure. As shown in Fig. 3A, the cell viability decreased slightly with the concentration or incubation time, but it was above $85 \%$ even at a high concentration $(64 \mu \mathrm{g} / \mathrm{mL})$, indicating the low cytotoxicity of $\mathrm{Gd}_{2} \mathrm{O}_{3} \mathrm{NPs}$ in HeLa cells. Cisplatin at a low dose $(5 \mu \mathrm{g} / \mathrm{mL}$ ) killed about $10 \%$ of the HeLa cells, while treatment for $24 \mathrm{~h}$ with a combination of 4 (or 8 ) $\mu \mathrm{g} / \mathrm{mL} \mathrm{Gd}_{2} \mathrm{O}_{3} \mathrm{NPs}$ and $5 \mu \mathrm{g} / \mathrm{mL}$ cisplatin increased the HeLa cell death rate to about $20 \%$, as assessed by MTT assay (Fig. 3B). The microscopy images support this conclusion, with more cells dying when cotreated with chemical drug and $8 \mu \mathrm{g} / \mathrm{mL} \mathrm{Gd}_{2} \mathrm{O}_{3}$ NPs compared with each agent alone (Fig. $3 \mathrm{C}$ ).

Autophagic blocking contributed to enhanced cytotoxicity

Autophagy is a major method of cancer cells to combat chemical drugs. Thus, to find out whether the blocked autophagic flux caused by $\mathrm{Gd}_{2} \mathrm{O}_{3} \mathrm{NPs}$ is responsible for the enhanced cytotoxicity, we assessed how low-dose $\mathrm{Gd}_{2} \mathrm{O}_{3} \mathrm{NPs}$ affect the cell death caused by $5 \mu \mathrm{g} / \mathrm{mL}$ cisplatin, a frequently used chemotherapeutic agent. Cell death induced by cisplatin is known as apoptosis [26]. For quantification of apoptotic cells, the HeLa cells were stained with Annexin V-FITC and PI after $24 \mathrm{~h}$ of treatment. The results showed that the combination of $8 \mu \mathrm{g} / \mathrm{mL} \mathrm{Gd}_{2} \mathrm{O}_{3} \mathrm{NPs}$ and $5 \mu \mathrm{g} / \mathrm{mL}$ cisplatin caused twice the apoptotic cell number compared to $5 \mu \mathrm{g} / \mathrm{mL}$ cisplatin alone. Treatment with $8 \mu \mathrm{g} / \mathrm{mL} \mathrm{Gd}_{2} \mathrm{O}_{3} \mathrm{NPs}$ alone did not cause a significant increase in the number of apoptotic cells (Fig. 4A).

To find out whether the blockage of the autophagic flux is responsible for the cell death, we replaced $\mathrm{Gd}_{2} \mathrm{O}_{3} \mathrm{NPs}$ with $100 \mathrm{nM} C Q$ in the co-treatment of HeLa cells with cisplatin. We then estimated the 
number of apoptotic cells as we had done before. The number of apoptotic cells caused by the combination of $100 \mathrm{nM} \mathrm{CQ}$ and $5 \mu \mathrm{g} / \mathrm{mL}$ cisplatin was increased by about $100 \%$ than the number caused by $5 \mu \mathrm{g} / \mathrm{mL}$ cisplatin alone (Fig. 4B). These results indicated that $\mathrm{Gd}_{2} \mathrm{O}_{3}$ NPs can enhance cisplatinmediated cell death.

To provide more proof, $20 \mu \mathrm{M}$ Rapa was used to recover the autophagic flux impaired by $\mathrm{Gd}_{2} \mathrm{O}_{3} \mathrm{NPs}$. As shown in Fig. 5, not only did $20 \mu \mathrm{M}$ Rapa decrease the level of p62 accumulation induced by $8 \mu \mathrm{g} / \mathrm{mL}$ $\mathrm{Gd}_{2} \mathrm{O}_{3} \mathrm{NPs}$ (Fig. $5 \mathrm{C}$ and D), indicating that Rapa can indeed recover autophagic flux impaired by $\mathrm{Gd}_{2} \mathrm{O}_{3}$ $\mathrm{NPs}$, but Rapa also significantly reduced the chemosensitization caused by $\mathrm{Gd}_{2} \mathrm{O}_{3} \mathrm{NPs}$. With the addition of Rapa, about $20 \%$ more cells survived when co-treated with $\mathrm{Gd}_{2} \mathrm{O}_{3}$ NPs and cisplatin (Fig. 5A and B). These results indicated that inhibition of autophagic flux is required for chemosensitization induced by $\mathrm{Gd}_{2} \mathrm{O}_{3}$ NPs.

$\mathrm{Gd}_{2} \mathrm{O}_{3} \mathrm{NPs}$ also enhance chemosensitization in cisplatin-resistant cancer cells

Some tumor cells develop resistance to chemotherapeutics via autophagy; thus, inhibiting autophagy could be a promising strategy for cancer therapy [11]. To assess whether the sensitization effect is HeLaspecific, we evaluated the chemosensitization effect of $\mathrm{Gd}_{2} \mathrm{O}_{3} \mathrm{NPs}$ in cisplatin-resistant cancer cells, COC1/DDP, using an Annexin V/PI assay. Similar to the situation with HeLa cells, the combination of 8 $\mu \mathrm{g} / \mathrm{mL} \mathrm{Gd}_{2} \mathrm{O}_{3} \mathrm{NPs}$ and $10 \mu \mathrm{g} / \mathrm{mL}$ cisplatin resulted in a lower cell viability (Figure S1), compared to treat with cisplatin alone, number of dead cells increased by about $100 \%$ (Figure 6). This result indicated that the chemosensitization effect of $\mathrm{Gd}_{2} \mathrm{O}_{3}$ NPs was also efficient in COC1/DDP cells.

\section{Discussion}

The most difficult factor that we confront when treating cancer is drug resistance among cancer cells [27], and autophagy is an important reason for drug resistance. Several nano-materials have been found to induce cancer cell death by causing autophagy failure [28]. Moreover, due to the enhanced permeability and retention (EPR) effect at tumor sites, NPs mainly become distributed at tumor sites [29], which means that NPs could improve the efficacy of chemotherapy. Nanomaterials such as $\mathrm{C60}$ and MnO nanocrystal may kill cancer cells by inducing autophagy, and they have the potential for use in cancer therapy $[8,9]$.

In this study, we found that $\mathrm{Gd}_{2} \mathrm{O}_{3} \mathrm{NPs}$ had a strong ability to block autophagic flux and could result in cancer cell death when used with chemical drugs to treat cancer cells. We were convinced that the autophagic response induced by $\mathrm{Gd}_{2} \mathrm{O}_{3} \mathrm{NPs}$ increased with the concentration of $\mathrm{Gd}_{2} \mathrm{O}_{3} \mathrm{NPs}$ (Fig. 1), and the chemosensitization effect of $\mathrm{Gd}_{2} \mathrm{O}_{3}$ NPs also increased (Fig. 3B). The results demonstrated the interrelationship between the observed autophagic flux impairment and the chemosensitization effects of 
$\mathrm{Gd}_{2} \mathrm{O}_{3} \mathrm{NPs}$. The autophagy failure occurred because of autophagosome accumulation caused by blockage of the late stage of autophagic flux rather than induction of autophagy.

The same chemosensitization effects occurred in both drug-resistant cancer cells and ordinary nonresistant cancer cells after exposure to $\mathrm{Gd}_{2} \mathrm{O}_{3} \mathrm{NPs}$. $\mathrm{Gd}_{2} \mathrm{O}_{3}$ nanomaterials are a great candidate for MRI. Thus, the $\mathrm{Gd}_{2} \mathrm{O}_{3}$ NPs used in our work have great potential to be used as a tool for both cancer diagnosis and treatment.

\section{Declarations}

Ethics approval and consent to participate

Not applicable. This manuscript does not report on or involve the use of any animal or human data or tissue.

Consent for publication

Not applicable. This manuscript does not contain data from any individual person.

Availability of data and materials

The datasets used and/or analysed during the current study are available from the corresponding author on reasonable request.

Competing interests

The authors declare that they have no competing interests.

\section{Funding}

This work was supported by the National Basic Research Program of China (973 Program, no. 2013CB933904), and the National Natural Science Foundation of China (31570090 and 21272182). This project is partially supported by National Infrastructure of Natural Resources for Science and Technology Program of China (no. NIMR-2018-8), and the Laboratory (Innovative) Research Fund of Wuhan University.

\section{Authors' contributions}

Tianyu Zhang, Cheng Zhong and Zhixiong Xie contributed to the conception and design of this work. Both Tianyu Zhang and Cheng Zhong contributed to the cell culture and treatment, Tianyu Zhang contributed to the acquisition of all westernblot data, Cheng Zhong contributed to the acquisition of MDC, immunofluorescence and MTT data, both Tianyu Zhang and Cheng Zhong contributed to the acquisition of flow cytometry data. Tianyu Zhang and Zhixiong Xie contributed to the analysis and interpretation of 
all the data. Tianyu Zhang contributed to drafting the article, Zhixiong Xie and Tianyu Zhang contributed to revising it critically for important intellectual content.

Acknowledgments

The $\mathrm{Gd}_{2} \mathrm{O}_{3}$ NPs used in this work were created by Mr. Bin W. Ren in Prof. Jinhao Gao's lab at Xiamen University. Thanks for Dr. Junpeng Fan in Prof. Zhixiong Xie's lab at Wuhan University for the imparting of experimental skills and knowledge of autophagy.

\section{References}

1. Hanahan D, Weinberg RA. The Hallmarks of Cancer. Cell. 2000;100(1):57-70.

2. Malhotra V, Perry MC. Classical Chemotherapy: Mechanisms, Toxicities and the Therapeutc Window. Cancer Biology \& Therapy. 2014;2(sup1):1-3.

3. Makin G, Dive C. Apoptosis and cancer chemotherapy. Trends in Cell Biology. 2001;11:S22-S6.

4. Sui X, Chen R, Wang Z, Huang Z, Kong N, Zhang M, et al. Autophagy and chemotherapy resistance: a promising therapeutic target for cancer treatment. Cell death \& disease. 2013 Oct 10;4:e838. PubMed PMID: 24113172. Pubmed Central PMCID: 3824660.

5. Klionsky DJ. Autophagy: from phenomenology to molecular understanding in less than a decade. Nature reviews Molecular cell biology. 2007 Nov;8(11):931-7. PubMed PMID: 17712358.

6. Stern ST, Adiseshaiah PP, Crist RM. Autophagy and lysosomal dysfunction as emerging mechanisms of nanomaterial toxicity. Particle and fibre toxicology. 2012 Jun 14;9:20. PubMed PMID: 22697169. Pubmed Central PMCID: 3441384.

7. Fan J, Shao M, Lai L, Liu Y, Xie Z. Inhibition of autophagy contributes to the toxicity of cadmium telluride quantum dots in Saccharomyces cerevisiae. International journal of nanomedicine. 2016;11:3371-83. PubMed PMID: 27524895. Pubmed Central PMCID: 4966502.

8. Zhang Q, Yang W, Man N, Zheng F, Shen Y, Sun K, et al. Autophagy-mediated chemosensitization in cancer cells by fullerene C60 nanocrystal. Autophagy. 2014;5(8):1107-17.

9. Lu Y, Zhang L, Li J, Su Y-D, Liu Y, Xu Y-J, et al. MnO Nanocrystals: A Platform for Integration of MRI and Genuine Autophagy Induction for Chemotherapy. Advanced Functional Materials. 2013;23(12):1534-46.

10. Li J, Hou N, Faried A, Tsutsumi S, Kuwano H. Inhibition of autophagy augments 5-fluorouracil chemotherapy in human colon cancer in vitro and in vivo model. European journal of cancer. 2010 Jul;46(10):1900-9. PubMed PMID: 20231086.

11. Guo XL, Li D, Hu F, Song JR, Zhang SS, Deng WJ, et al. Targeting autophagy potentiates chemotherapy-induced apoptosis and proliferation inhibition in hepatocarcinoma cells. Cancer letters. 2012 Jul 28;320(2):171-9. PubMed PMID: 22406827.

12. Cho M, Sethi R, Narayanan JS, Lee SS, Benoit DN, Taheri N, et al. Gadolinium oxide nanoplates with high longitudinal relaxivity for magnetic resonance imaging. Nanoscale. 2014 Nov 21;6(22):13637- 
45. PubMed PMID: 25273814.

13. Chen F, Chen M, Yang C, Liu J, Luo N, Yang G, et al. Terbium-doped gadolinium oxide nanoparticles prepared by laser ablation in liquid for use as a fluorescence and magnetic resonance imaging dualmodal contrast agent. Physical chemistry chemical physics : PCCP. 2015 Jan 14;17(2):1189-96. PubMed PMID: 25418675.

14. Ahren M, Selegard L, Klasson A, Soderlind F, Abrikossova N, Skoglund C, et al. Synthesis and characterization of PEGylated Gd2O3 nanoparticles for MRI contrast enhancement. Langmuir : the ACS journal of surfaces and colloids. 2010 Apr 20;26(8):5753-62. PubMed PMID: 20334417.

15. Kattel K, Park JY, Xu W, Kim HG, Lee EJ, Bony BA, et al. A facile synthesis, in vitro and in vivo MR studies of d-glucuronic acid-coated ultrasmall $\operatorname{Ln}(2) \mathrm{O}(3)$ ( $\mathrm{Ln}=\mathrm{Eu}, \mathrm{Gd}, \mathrm{Dy}, \mathrm{Ho}$, and Er) nanoparticles as a new potential MRI contrast agent. ACS applied materials \& interfaces. 2011 Sep;3(9):3325-34. PubMed PMID: 21853997.

16. Ni K, Zhao Z, Zhang Z, Zhou Z, Yang L, Wang L, et al. Geometrically confined ultrasmall gadolinium oxide nanoparticles boost the T(1) contrast ability. Nanoscale. 2016 Feb 14;8(6):3768-74. PubMed PMID: 26814592.

17. Faucher L, Guay-Begin AA, Lagueux J, Cote MF, Petitclerc E, Fortin MA. Ultra-small gadolinium oxide nanoparticles to image brain cancer cells in vivo with MRI. Contrast media \& molecular imaging. 2011 Jul-Aug;6(4):209-18. PubMed PMID: 21861281.

18. Yoshimori T. Autophagy: a regulated bulk degradation process inside cells. Biochemical and Biophysical Research Communications. 2004;313(2):453-8.

19. Klionsky DJ. Autophagy as a Regulated Pathway of Cellular Degradation. Science. 2000;290(5497):1717-21.

20. Li R, Ji Z, Qin H, Kang X, Sun B, Wang M, et al. Interference in autophagosome fusion by rare earth nanoparticles disrupts autophagic flux and regulation of an interleukin-1beta producing inflammasome. ACS nano. 2014 Oct 28;8(10):10280-92. PubMed PMID: 25251502. Pubmed Central PMCID: 4213039.

21. Vázquez CL, Colombo MI. Chapter 6 Assays to Assess Autophagy Induction and Fusion of Autophagic Vacuoles with a Degradative Compartment, Using Monodansylcadaverine (MDC) and DQ-BSA. 2009;452:85-95.

22. Klionsky DJ, Abeliovich H, Agostinis P, Agrawal DK, Aliev G, Askew DS, et al. Guidelines for the use and interpretation of assays for monitoring autophagy in higher eukaryotes. Autophagy. 2014:4(2):151-75.

23. Rubinsztein DC, Cuervo AM, Ravikumar B, Sarkar S, Korolchuk VI, Kaushik S, et al. In search of an “autophagomometer". Autophagy. 2014;5(5):585-9.

24. Mizushima N, Yoshimori T, Levine B. Methods in mammalian autophagy research. Cell. 2010 Feb 5;140(3):313-26. PubMed PMID: 20144757. Pubmed Central PMCID: 2852113.

25. Bjorkoy G, Lamark T, Brech A, Outzen H, Perander M, Overvatn A, et al. p62/SQSTM1 forms protein aggregates degraded by autophagy and has a protective effect on huntingtin-induced cell death. The 
Journal of cell biology. 2005 Nov 21;171(4):603-14. PubMed PMID: 16286508. Pubmed Central PMCID: 2171557.

26. Barry MA, Behnke CA, Eastman A. Activation of programmed cell death (apoptosis) by cisplatin, other anticancer drugs, toxins and hyperthermia. Biochemical Pharmacology. 1990;40(10):2353-62.

27. Pasquier J, Magal P, Boulange-Lecomte C, Webb G, Le Foll F. Consequences of cell-to-cell Pglycoprotein transfer on acquired multidrug resistance in breast cancer: a cell population dynamics model. Biology direct. 2011 Jan 26;6:5. PubMed PMID: 21269489. Pubmed Central PMCID: 3038988.

28. Kumar A, Singh UK, Chaudhary A. Targeting autophagy to overcome drug resistance in cancer therapy. Future medicinal chemistry. 2015 Aug;7(12):1535-42. PubMed PMID: 26334206.

29. Nakamura H, Jun F, Maeda H. Correction to: Development of next-generation macromolecular drugs based on the EPR effect: challenges and pitfalls. Expert opinion on drug delivery. 2015 Apr;12(4):691. PubMed PMID: 25739469.

\section{Figures}
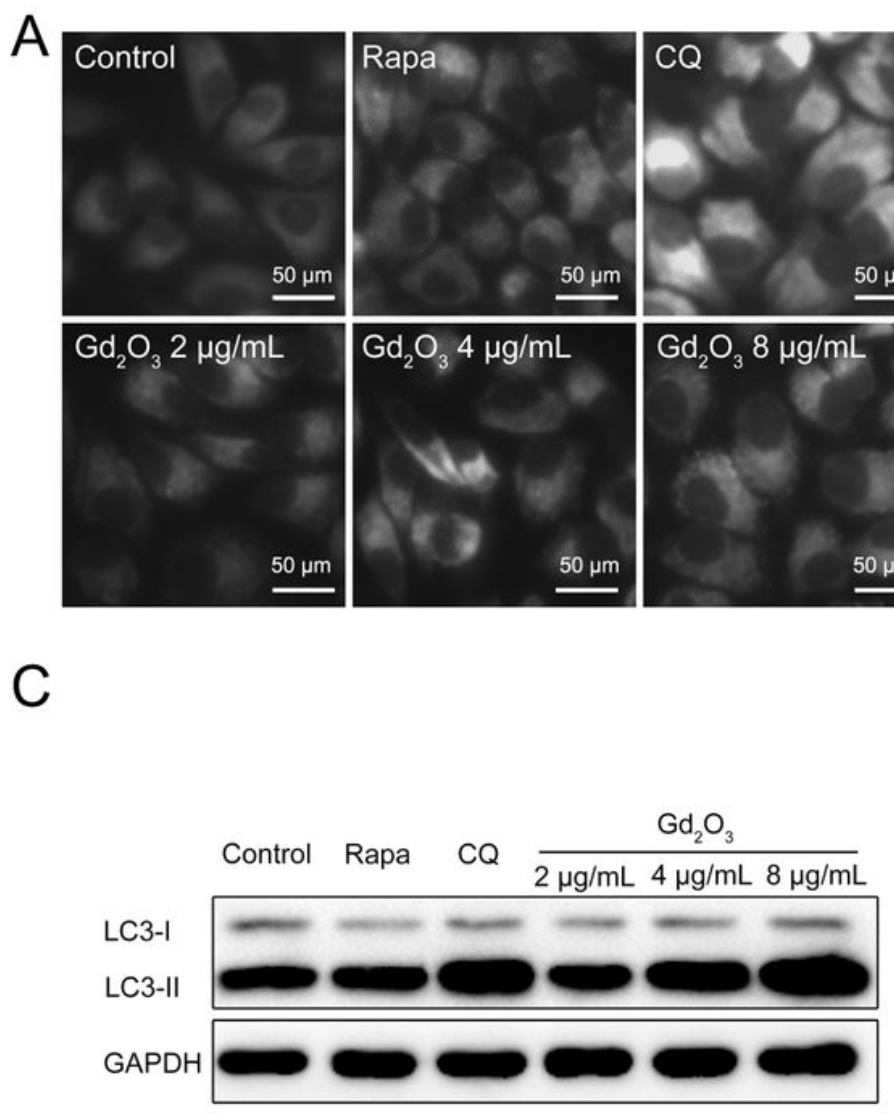
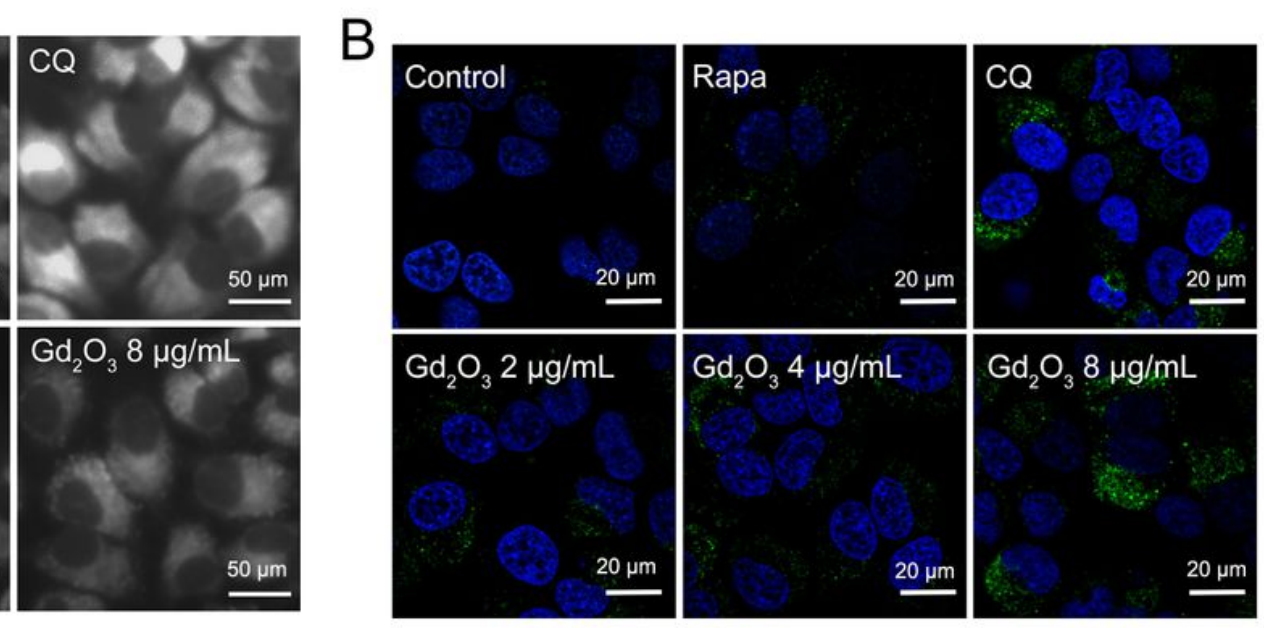

D

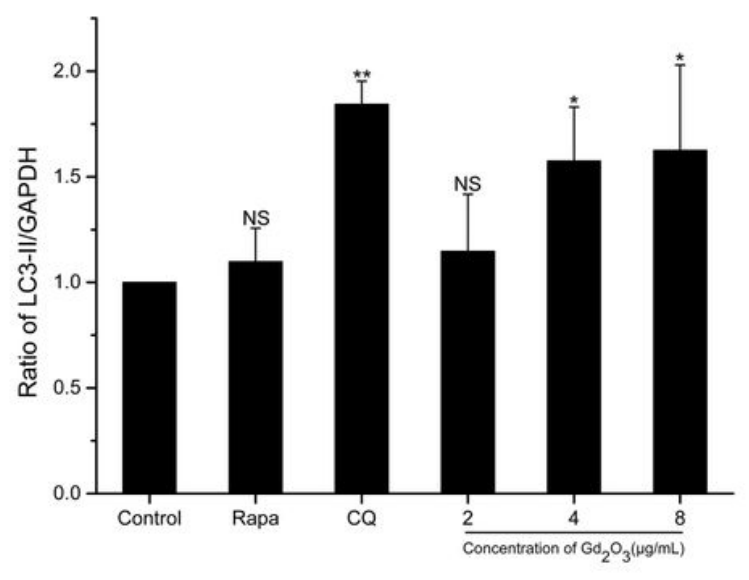

Figure 1 
Gd203 NPs cause autophagosome accumulation in a dose-dependent manner. Notes: After $24 \mathrm{~h}$ of treatment, (A) Monodasylcadaverine (MDC) staining showed that $4 \mu \mathrm{g} / \mathrm{mL}$ or $8 \mu \mathrm{g} / \mathrm{mL} \mathrm{Gd} 203 \mathrm{NPs}$ caused autophagosome accumulation. (B) Immunofluorescence of LC3 and (C) immunoblotting of LC3-II showed that $4 \mu \mathrm{g} / \mathrm{mL}$ or $8 \mu \mathrm{g} / \mathrm{mL}$ Gd2O3 NPs upregulate LC3 expression in a dose-dependent manner. (D) Quantification of (C). The ratio of LC3-II/GADPH in each group was calculated. The results are expressed as mean \pm standard deviation, $n=3$. ${ }^{\star} \mathrm{p} \otimes 0.05,{ }^{* \star} \mathrm{p}<0.01$. Abbreviations: Rapa, rapamycin; $\mathrm{CQ}$, chloroquine; Gd203, gadolinium oxide nanoparticles; NS, not significant.
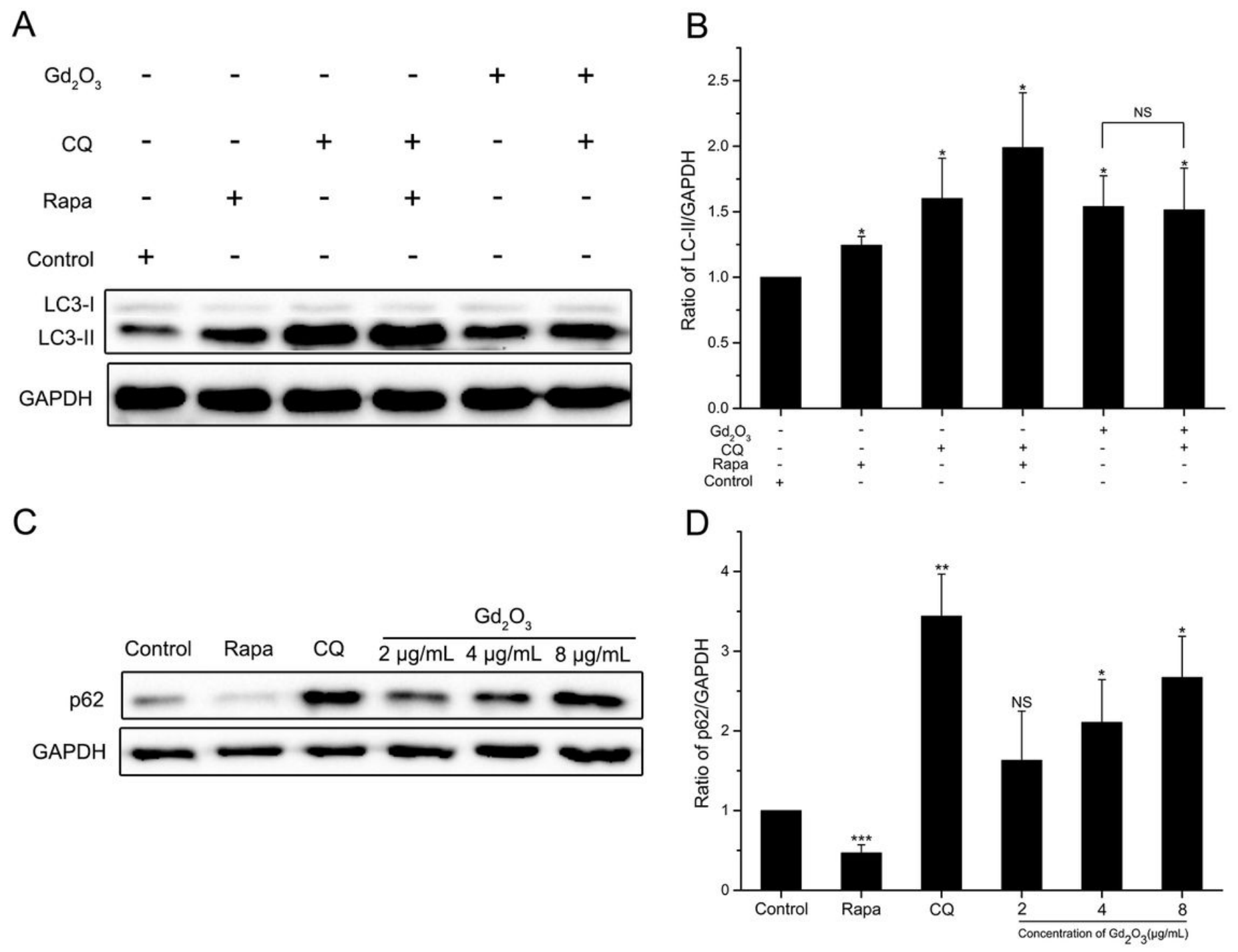

Figure 2

Inhibition of late-stage autophagic flux causes autophagosome accumulation. Notes: After $12 \mathrm{~h}$ of treatment, (A) $20 \mu \mathrm{M}$ Rapa increased the accumulation of LC3-II and the addition of $100 \mathrm{nM}$ CQ increased the accumulation further; $8 \mu \mathrm{g} / \mathrm{mL} \mathrm{Gd2O3} \mathrm{NPs} \mathrm{also} \mathrm{increased} \mathrm{the} \mathrm{amount} \mathrm{of} \mathrm{LC3-II} \mathrm{but} \mathrm{the} \mathrm{addition} \mathrm{of}$ $100 \mathrm{nM}$ CQ did not further increase the accumulation of LC3-II. (B) Quantification of (A). The ratio of LC3II/GADPH in each group was calculated. The results are expressed as mean \pm standard deviation, $n=3 .{ }^{*} \mathrm{p}$ $\nabla 0.05$. (C) $20 \mu \mathrm{M}$ Rapa and $100 \mathrm{nM} C Q$ caused the amount of p62 to be decreased and increased, respectively, and Gd203 NPs increased the amount of p62 in a dose-dependent manner. (D) 
Quantification of (C). The ratio of p62/GADPH in each group was calculated. The results are expressed as mean \pm standard deviation, $n=3 .{ }^{*} p<0.05 * * p<0.01 * * * p<0.001$. Abbreviations: Rapa, rapamycin; $C Q$, chloroquine; Gd203, gadolinium oxide nanoparticles; NS, not significant.
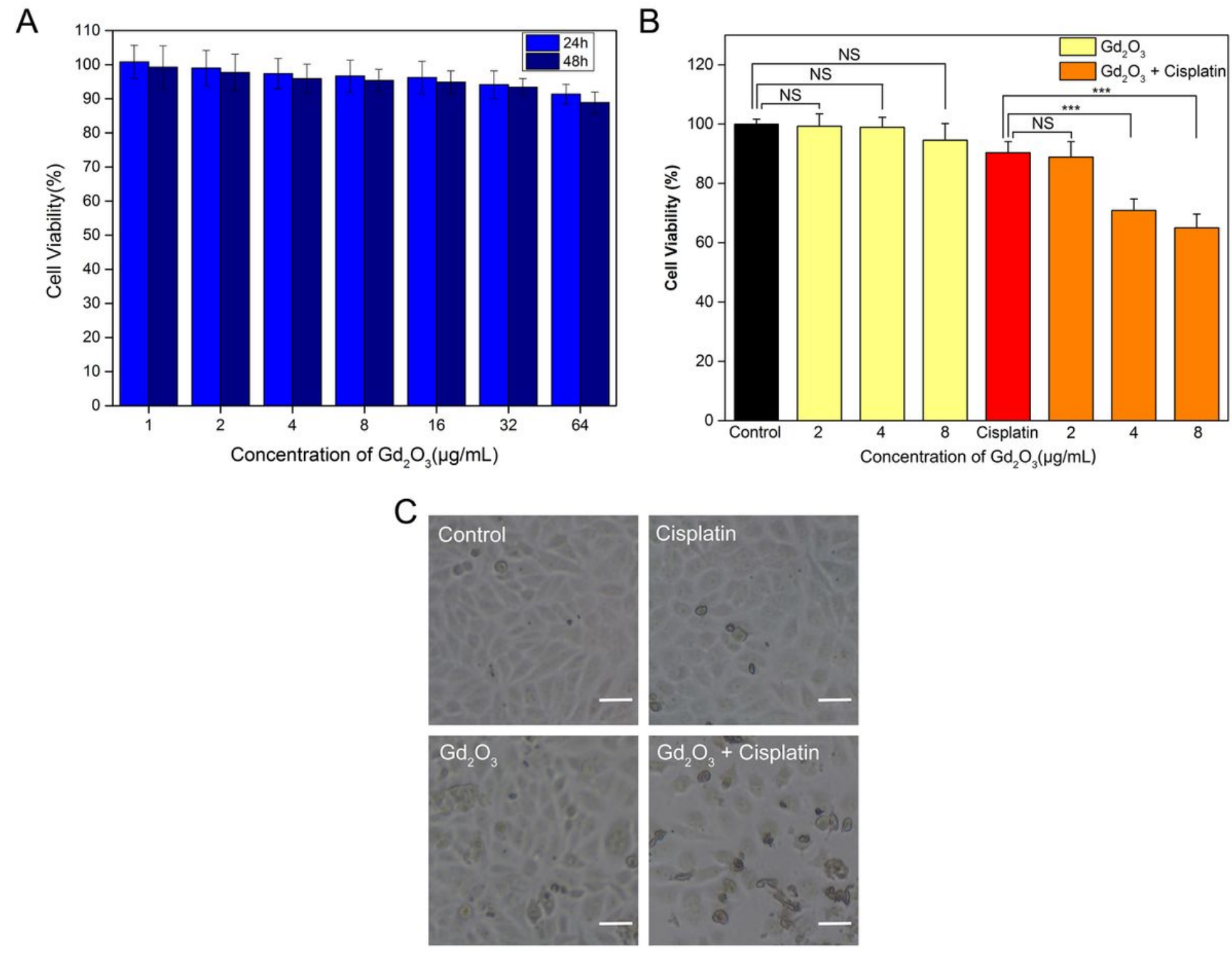

\section{Figure 3}

Gd203 NPs are responsible for the enhanced cytotoxicity of cisplatin Notes: (A) Gd203 NPs have a very limited cytotoxic effect on HeLa cells, even at a relatively high dose: $>90 \%$ of cells survived even after treatment for $48 \mathrm{~h}$ with $8 \mu \mathrm{g} / \mathrm{mL}$ Gd203 NPs. (B) $5 \mu \mathrm{g} / \mathrm{mL}$ cisplatin caused about $90 \%$ of the cells to die, while treatment of HeLa cells for $12 \mathrm{~h}$ with a combination of 4 or $8 \mu \mathrm{g} / \mathrm{mL} \mathrm{Gd} 203 \mathrm{NPs}$ and $5 \mu \mathrm{g} / \mathrm{mL}$ cisplatin killed about 20\% more HeLa cells. (C) Microscopy images showed the same effect described

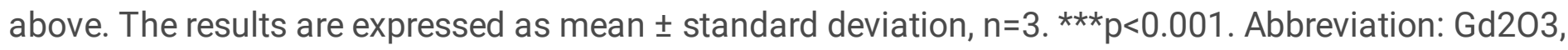
gadolinium oxide nanoparticles. NS, not significant. Scale bars: $50 \mu \mathrm{m}$ 
A

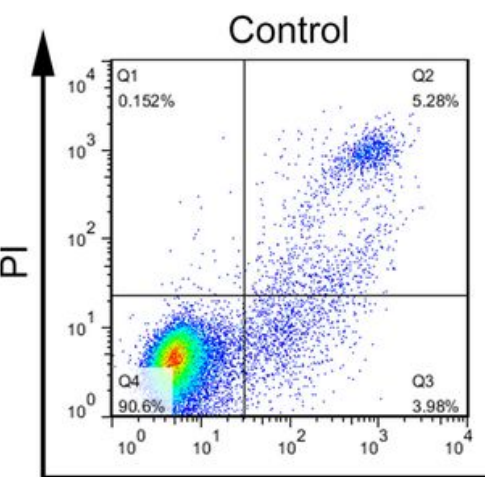

B

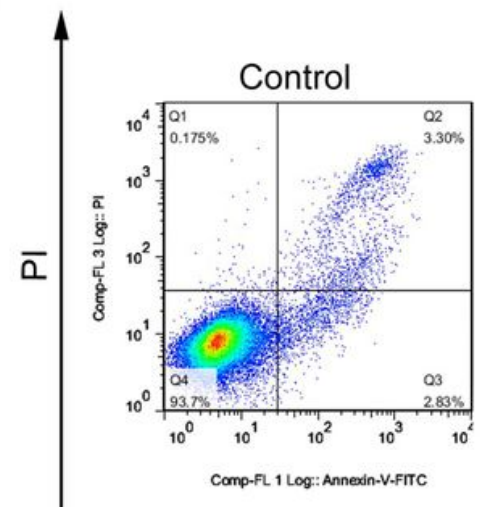

Cisplatin

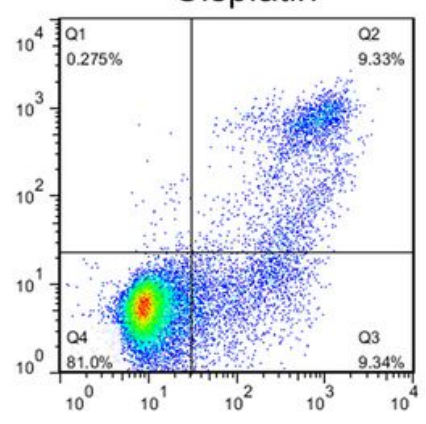

$\mathrm{Gd}_{2} \mathrm{O}_{3}$

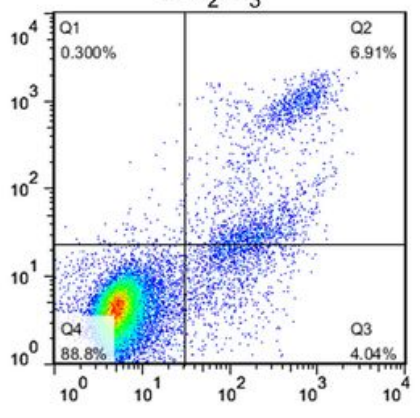

$\mathrm{Gd}_{2} \mathrm{O}_{3}+$ Cisplatin

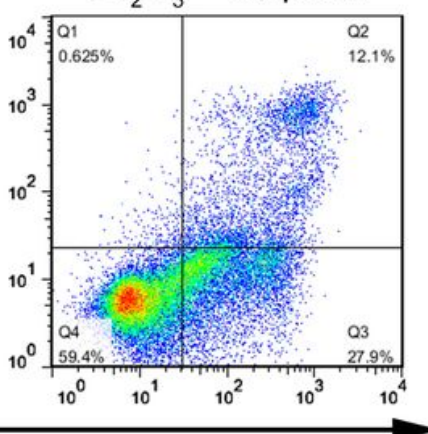

Annexin V
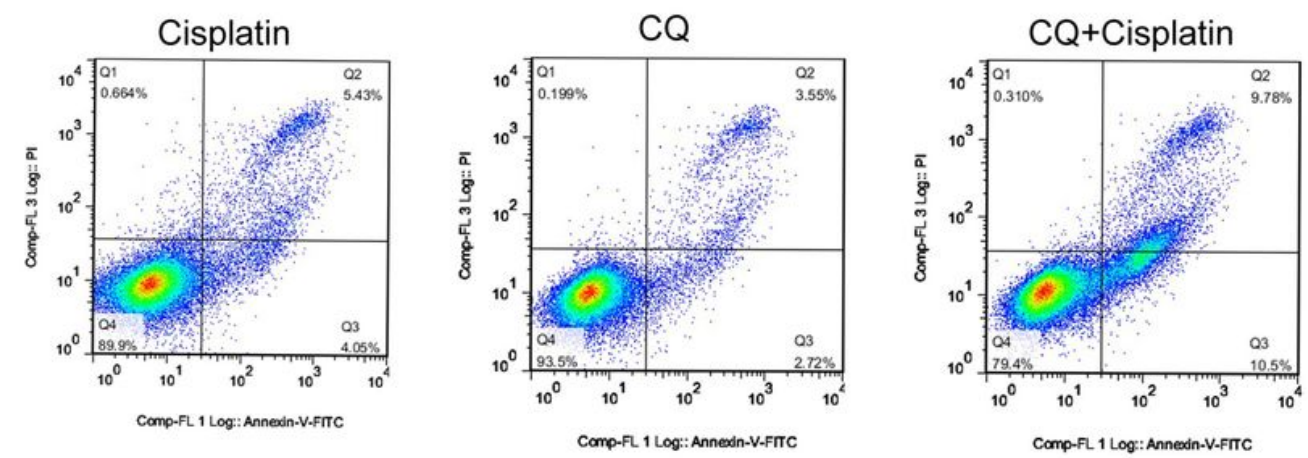

Annexin $\mathrm{V}$

\section{Figure 4}

Gd203 NPs and CQ showed the same pattern regarding the enhancement of cisplatin's cytotoxicity. Notes: (A) The combination of $8 \mu \mathrm{g} / \mathrm{mL}$ Gd2O3 NPs and $5 \mu \mathrm{g} / \mathrm{mL}$ cisplatin caused apoptotic cell death number increased by about $100 \%$ compared with $5 \mu \mathrm{g} / \mathrm{mL}$ cisplatin alone. Gd2O3 NPs alone had no effect on the number of apoptotic cells. (B) The combination of $100 \mathrm{nM} \mathrm{CQ}$ and $5 \mu \mathrm{g} / \mathrm{mL}$ cisplatin also caused apoptotic cell death number increased by about $100 \%$ compared with $5 \mu \mathrm{g} / \mathrm{mL}$ cisplatin alone. $100 \mathrm{nM} \mathrm{CQ}$ alone had no effect on the number of apoptotic cells. Abbreviations: Rapa, rapamycin; CQ, chloroquine; Gd203, gadolinium oxide nanoparticles. 
A

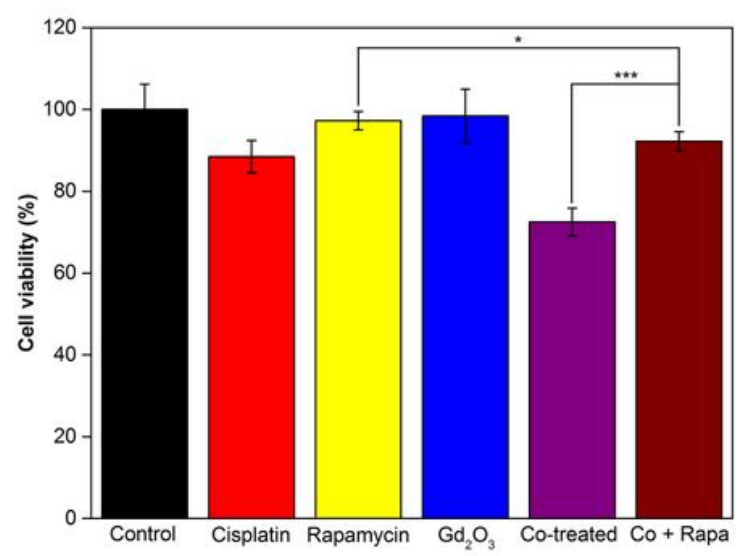

B

$\bar{\alpha}$

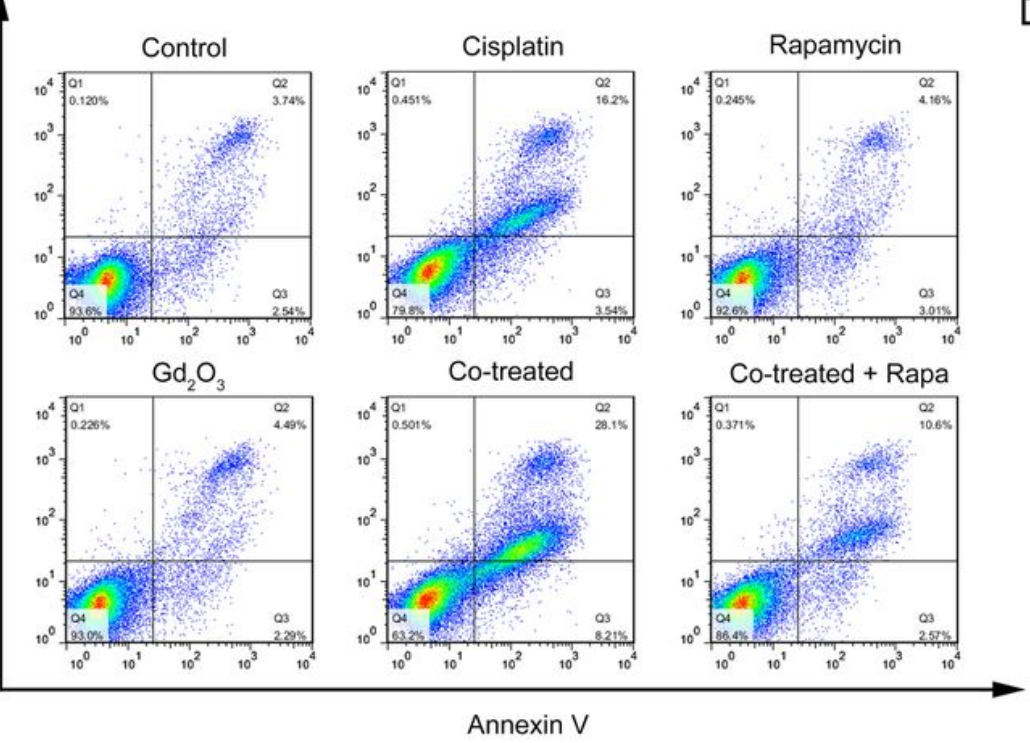

C

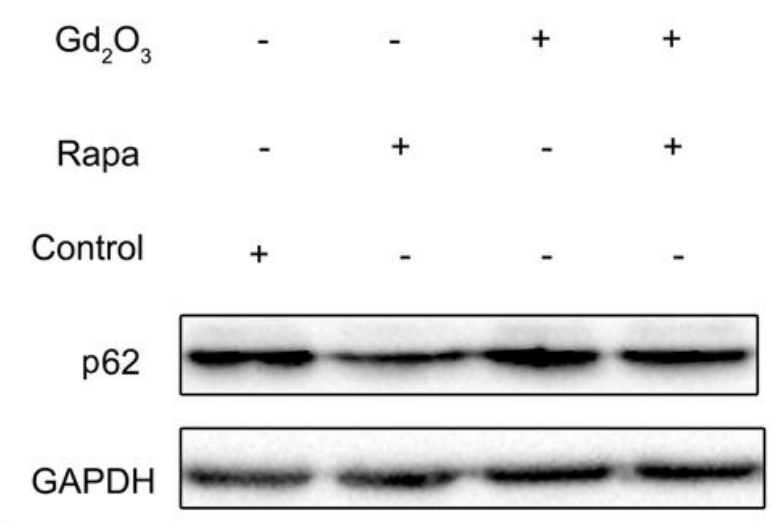

D

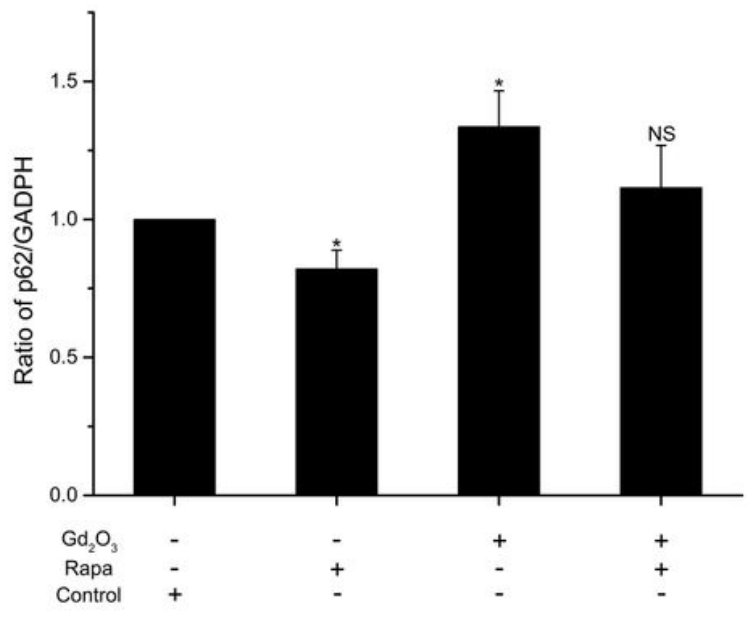

Figure 5

Rapamycin partially recovered the blocked autophagic flux and weakened the cytotoxicity of Gd2O3 NPs and cisplatin. Notes: (A) Autophagy promotor rapamycin $(20 \mu \mathrm{M})$ weakened the cytotoxicity of the combination of $8 \mu \mathrm{g} / \mathrm{mL} \mathrm{Gd} 203 \mathrm{NPs}$ and $5 \mu \mathrm{g} / \mathrm{mL}$ cisplatin in HeLa cells. The results are expressed as

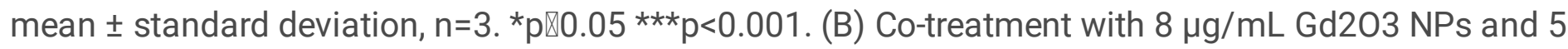
$\mu \mathrm{g} / \mathrm{mL}$ cisplatin with the addition of $20 \mu \mathrm{M}$ rapamycin decreased the apoptotic cell number. (C) $8 \mu \mathrm{g} / \mathrm{mL}$ Gd203 NPs increase the accumulation of p62 while $20 \mu \mathrm{M}$ rapamycin partly decreased the accumulation. (D) Quantification of (C). The ratio of p62/GADPH in each group was calculated. The results are expressed as mean \pm standard deviation, $n=3$. *p $₫ 0.05$. Abbreviations: Rapa, rapamycin; $C Q$, chloroquine; Gd203, gadolinium oxide nanoparticles. 


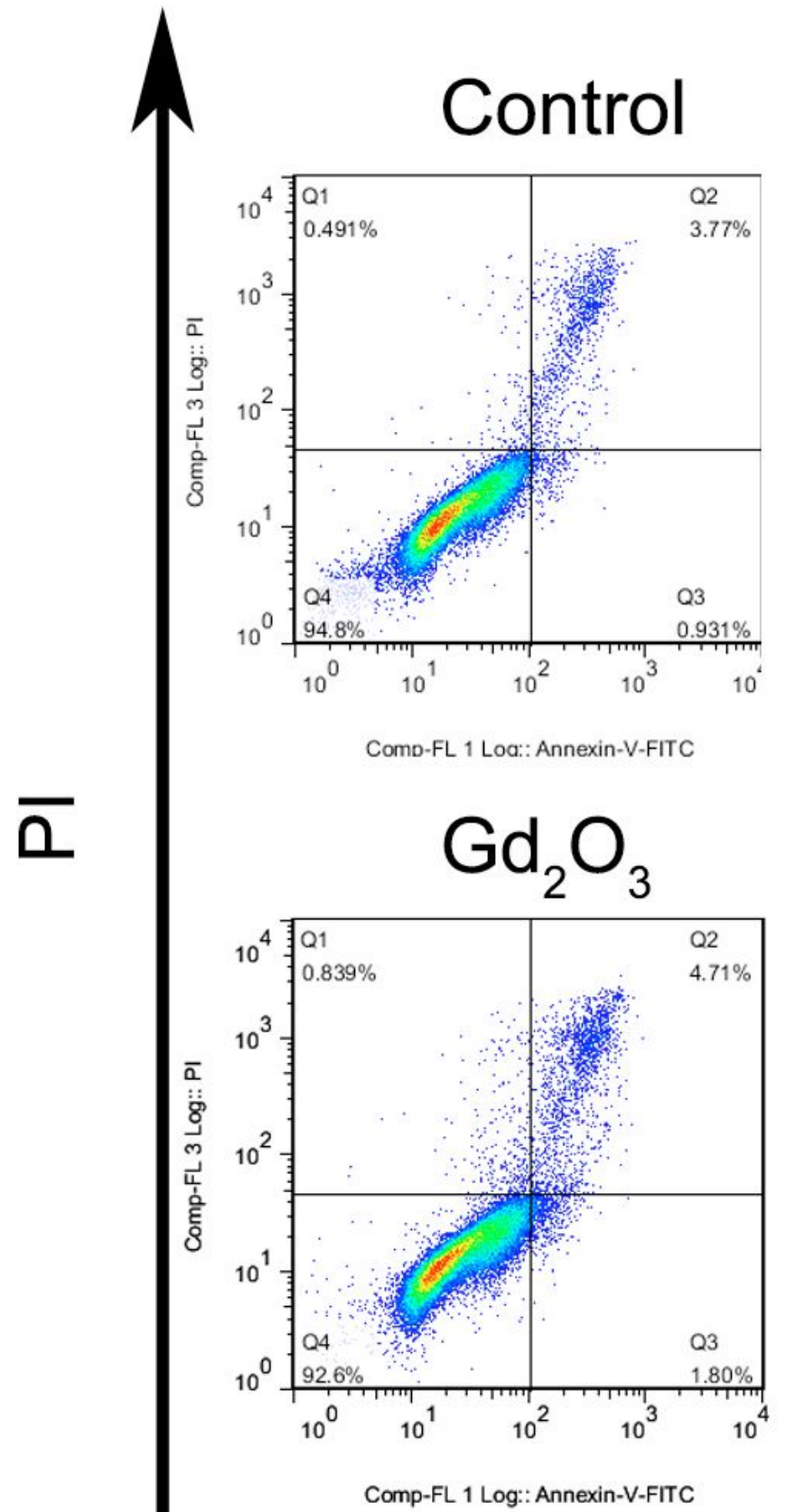

Cisplatin

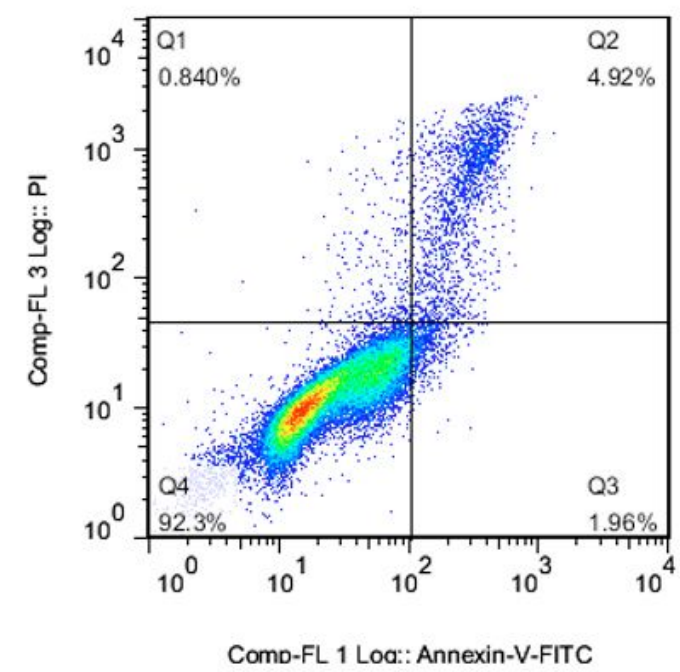

$\mathrm{Gd}_{2} \mathrm{O}_{3}+$ Cisplatin

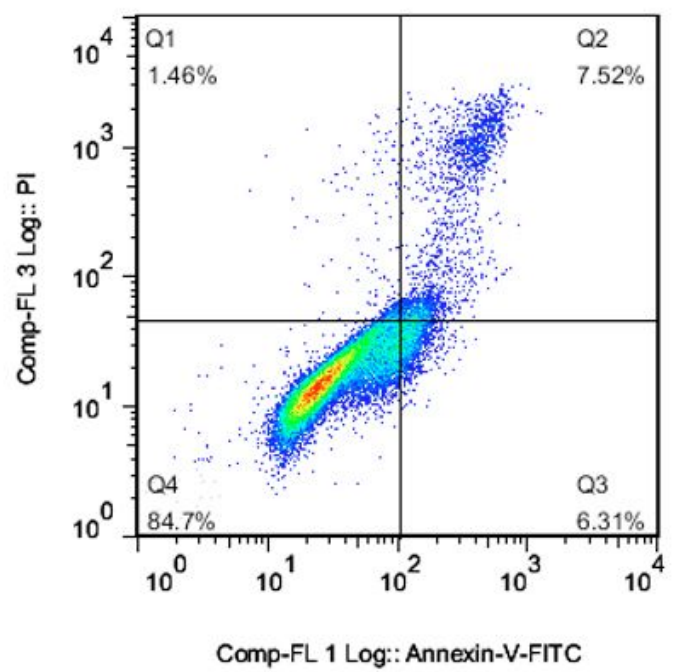

Annexin V

Figure 6

Chemosensitization efficacy of the combination of Gd2O3 NPs and cisplatin in cisplatin-resistant COC1/DDP cells. Notes: The apoptotic COC1/DDP cell number caused by the combination of $8 \mu \mathrm{g} / \mathrm{mL}$ Gd2O3 NPs and $10 \mu \mathrm{g} / \mathrm{mL}$ cisplatin increased by about $100 \%$ compared to the number caused by 10 $\mu \mathrm{g} / \mathrm{mL}$ cisplatin alone. $8 \mu \mathrm{g} / \mathrm{mL} \mathrm{Gd} 203$ NPs alone did not cause an increase in the COC1/DDP apoptotic cell death number. Abbreviations: Gd203, gadolinium oxide nanoparticles. 


\section{Supplementary Files}

This is a list of supplementary files associated with this preprint. Click to download.

- supplement1.jpg 